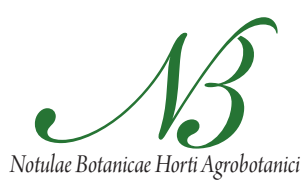

Cluj-Napoca

\title{
The Infection Processes of Sclerotinia sclerotiorum in Basal Stem Tissue of a Susceptible Genotype of Helianthus annuus L.
}

\author{
Robab DAVAR ${ }^{1 *}$, Reza DARVISHZADEH ${ }^{2}$, Ahmad MAJD³, Ardashir \\ KHARABIAN MASOULEH ${ }^{4}$, Yobert GHOSTA \\ ${ }^{1}$ Payame Noor University, Faculty of Science, Department of Biology, 19395-3697 Tehran, Iran; Davar.Robab@gmail.com ("corresponding author) \\ ${ }^{2}$ Urmia University, Department of Agronomy and Plant Breeding, Urmia, Iran \\ ${ }^{3}$ Tarbiat Moallem University, Faculty of Science, Department of Biology, Tehran, Iran \\ ${ }^{4}$ Southern Cross University, Southern Cross Plant Science, Lismore, NSW 2480, Australia \\ ${ }^{5}$ Urmia University, Department of Plant Protection, Urmia, Iran
}

\begin{abstract}
Sunflower, Helianthus annuus L., is a major oil seed crop widely cultivated throughout the globe. White mold, caused by necrotrophic pathogen Sclerotinia sclerotiorum (Lib.) de Bary, is a common and widespread pathogen of sunflower. The infection process of $S$. sclerotiorum was studied in the stem base of infected host tissues by light microscopy and Hemi-thin sectioning techniques. Host-pathogen interactions were examined at the plant surface and cellular level of a susceptible genotype (C146), 12, 24 and 48 h of post inoculation. The results showed that the appressoria were formed and the hyphal strands branched upon contact of pathogen with the host surface. Moreover a direct penetration of fungal hyphae was observed through the cuticle within $12 \mathrm{~h}$ of inoculation. Microscopic observation of inoculated tissues after 24 hours revealed that fungal hyphae have developed both inter- and intra-cellular layer. Moreover, the fungal hyphae growth was incremental among and inside the host cells. The host cells were completely colonized by fungal mycelium 48 hour after inoculation, leading to a tissue collapse. The hyphae invaded the dead host tissues and emerged from the host tissue after extensive colonization. The present study has detailed the infection processes and pathogen development both at plant surface and inside the host tissues. The results of this study will be useful for engineering of disease-resistant genotypes and development of markers for screening pathogen resistance individuals.
\end{abstract}

Keywords: basal stem rot, microscopy, plant-pathogen interaction, sunflower, white mold

\section{Introduction}

White mold, caused by the necrotrophic fungal pathogen Sclerotinia sclerotiorum (Lib.) de Bary, is one of the most devastating and cosmopolitan soil borne plant pathogen that infects over 500 species of plants worldwide including important field and fruit crops, ornamentals, trees, shrubs and numerous weeds (Saharan and Mehta, 2008; Garg et al., 2010). The majority of these hosts are dicotyledonous plants, although a number of agriculturally significant monocotyledonous plants such as onions and tulips are also host of this pathogen (Boland and Hall, 1994). Among the various hosts, sunflower (Helianthus annuus L.) is an important plant species that is susceptible to $S$. sclerotiorum infection, almost during its entire life cycle. Sunflower cotyledons, apical buds, base of stems, leaves and heads are usually susceptible to infection (Gulya et al., 1997). S. sclerotiorum causes stem rot in sunflower which is one of the most important plant diseases in many areas of the world, mainly due to lack of effective control- ling systems. Rapid drying of the leaves and development of lesions on the tap roots and basal portion of the stem provoke plants to die within a few days after the onset of wilting (Dorrell and Huang, 1978). Yield losses can reach $100 \%$ when the climatic conditions are suitable for the fungus (Sackston, 1992). In Iran, infection of sunflower by basal stem disease is considered as a potential threat that seriously affects crop production. The pathogen (fungus) is recognized by the fluffy white mycelium and black sclerotia that develops on the surface of lesions (Bolton et al., 2006).

To date, a number of sunflower genotypes with different levels of resistance to stem rot have been identified, but no full-resistant genotype has been reported yet (Hahn, 2002). Therefore, development of resistant varieties through breeding programes is an important aim. Management of plant diseases through chemical and cultural practices are usually ineffective and the level of host resistance to the pathogen is inadequate (Bolton et al., 2006; Li et al., 2008). Studies of host-pathogen interactions at 
144

the cellular level will contribute to the development of more effective disease-control measures (Tariq and Jeffries, 1986).

The compatible interaction of $S$. sclerotiorum with several different host species has been studied since the pioneering work of de Bary $(1886,1887)$ who demonstrated the formation of appresoria from germinating ascospores. Subsequent researches were undertaken in bean (Abawi et al., 1975; Lumsden and Dow, 1973; Lumsden and Wergin, 1980; Tariq and Jeffries, 1986), soybean (Sutton and Deverall, 1983), lettuce (Purdy, 1958; Tariq and Jeffries, 1984), tomato (Purdy and Bardin, 1953; Purdy, 1958), potato (Jones, 1976), pea (Huang and Kokko, 1992), oilseed rape (Garg et al., 2010; Huang et al., 2008) as well as in sunflower (Rodriguez et al., 2004; Sedun and Brown, 1987). All above investigations reported the infection processes of $S$. sclerotiorum in compatible interactions. These studies demonstrated that fungal pathogen may enter into plant cells through direct penetration, enzyme and toxin effects, mechanical pressure, or indirectly through wounds or natural openings such as lenticels or stomata (Isacc, 1992). Different tissues of the host plant (stem, root, cotyledon petiole, leaf petiole, etc.) can be penetrated differently by the same fungus. Each species of fungal pathogen may display different ways to penetrates host under different conditions (Isacc, 1992). In most cases, Sclerotinia penetrates directly the cuticle by appressoria and not through stomata (Boyle, 1921). The enzymatic digestion of the cuticle also plays a role in the penetration process (Tariq and Jeffries, 1986).

Pathogenic fungi usually facilitate the host colonization process by production of a wide range of cell wall degrading enzymes (CWDEs), including pectinases, $\beta-1,3$ glucanases, glycosidases, cellulases, xylanases and cutinases (Annis and Goodwin, 1997). It was also shown that S. sclerotiorum is capable for synthesizing extracellular CWDEs and oxalic acid (Bolton et al., 2006; Donaldson et al., 2001; Godoy et al., 1990; Lumsden, 1976; Marciano et al., 1982, 1983; Maxwell and Lumdsen, 1970) which is accumulated in the water-soaked lesions (Riou et al., 1991). During the host-pathogen interaction, S. sclerotiorum secretes CWDEs that can facilitate penetration, tissues maceration and degradation of plant cell wall components (Riou et al., 1991).

The ability of Sclerotinia spp. to invade the host and the mode of penetration into host tissues depend on the type of inoculum, the nutrient status of the fungus, properties of the host and effects of the surrounding environment. Two types of inoculums can initiate infection such as, germinated ascospores and mycelia (Abawi et al., 1975). In stem rot disease of sunflower, myceliogenic germination of soil-borne sclerotia results in mycelia that can directly attack plant tissues (Holley and Nelson, 1986).

However, no sufficient structural studies have been conducted yet on mode of penetration and interactions of sunflower basal stem and S. sclerotiorum during the infection process.

The aim of present work is to provide cellular and histological information during the infection process and to describe the infection processes of $S$. sclerotiorum on sunflower basal stem.

\section{Materials and methods}

\section{Plant materials}

$\mathrm{C} 146$ is a $\mathrm{F}_{9}$ recombinant inbred line (RIL) coming from a cross between PAC2 and RHA266 (Poormohammad Kiani et al., 2007). C146 is susceptible to Sclerotinia basal stem rot (Davar et al., 2010). Seeds of C146 line were sown in $10 \times 12 \mathrm{~cm}$ pots filled with sterilized soil after surface sterilization with a $6 \%$ sodium hypochlorite solution and three washes in sterile distilled water. Tab. 1 summarizes the properties of the soil used in the experiments. The soil was silty clay with a $\mathrm{pH}$ of 7.6 and an EC of $0.6 \mathrm{dSm}$ 1. Plants were grown in a controlled environment with a $12 \mathrm{~h}$ day with a day-light intensity of $200 \mathrm{mEm}^{-2} \mathrm{~s}^{-1}, 65 \%$ relative humidity and a day/night temperature of $24 / 18$ $\left( \pm 1^{\circ} \mathrm{C}\right)$ for 4 weeks, until they reached to growth stage V6V8 (Schneiter and Miller, 1981).

\section{Fungal isolate and inoculums production}

The fungal isolate SSU107 was previously isolated from an infected sunflower and reported to be moderately pathogenic on sunflower hybrid cv. 'Iroflor' (Davar et al., 2010). The isolate were grown on PDA [(Potato Dextrose $\operatorname{Agar}\left(39 \mathrm{gl}^{-1}, \mathrm{pH} 6\right.$, Merck)] medium and were incubated in the dark at room temperature $\left(25^{\circ} \mathrm{C}\right)$ for 3 days.

\section{Artificial inoculation}

At V6-V8 growth stage, mycelial plugs of the isolate (3 $\mathrm{mm}$ diameter) were cut from the growing edge of the colony (3-day-old on PDA) and were placed against the basal Tab. 1. Some physical and chemical properties of the soil used in this study (average values)

\begin{tabular}{ccccccccc}
\hline Soil parameters & $\mathrm{pH}$ & $\begin{array}{c}\mathrm{Ec} \times 10^{3} \\
(\mathrm{dS} \mathrm{m})^{-1}\end{array}$ & $\begin{array}{c}\mathrm{P} \\
\left(\mathrm{mg} \mathrm{kg}^{-1}\right)\end{array}$ & $\begin{array}{c}\mathrm{K} \\
\left(\mathrm{mg} \mathrm{kg}^{-1}\right)\end{array}$ & $\begin{array}{c}\mathrm{N}(\text { Total }) \\
(\%)\end{array}$ & $\begin{array}{c}\mathrm{Mg} \\
\left(\mathrm{meql}^{-1}\right)\end{array}$ & $\begin{array}{c}\mathrm{Ca} \\
\left(\mathrm{meql}^{-1}\right)\end{array}$ \\
\hline $\bar{X}$ & 7.60 & 0.60 & 39.3 & 565 & 0.11 & 1.87 & 1.89 \\
\hline Soil parameters & $\begin{array}{c}\mathrm{Cl} \\
\left(\mathrm{meql}^{-1}\right)\end{array}$ & $\begin{array}{c}\mathrm{OC}^{\mathrm{b}} \\
(\%)\end{array}$ & $\begin{array}{c}\mathrm{SP} \\
(\%)\end{array}$ & $\begin{array}{c}\mathrm{CaCO}_{3} \\
(\%)\end{array}$ & $\begin{array}{c}\mathrm{HCO}_{3} \\
(\%)\end{array}$ & $\begin{array}{c}\text { Sand } \\
(\%)\end{array}$ & $\begin{array}{c}\text { Silt } \\
(\%)\end{array}$ & $\begin{array}{c}\mathrm{Clay} \\
(\%)\end{array}$ \\
\hline $\bar{X}$ & 0.80 & 0.73 & 49.9 & 11.84 & 3.57 & 16 & 44 & 40 \\
\hline
\end{tabular}

${ }^{a}$ Ec $\times 10^{3}$, electrical conductivity; ${ }^{b} \mathrm{OC}$, organic carbon; ${ }^{\mathrm{c}} \mathrm{SP}$, saturation percentage 
stem of the sunflower plants. The stem and mycelial plug were wrapped with Parafilm for $48 \mathrm{~h}$ to preserve humidity, following the method of Price and Colhoun (1975). Completely randomized design with three replications was used in this experiment. Observation of treatments were carried out at different time post inoculation intervals of 12,24 and $48 \mathrm{~h}$.

\section{Sample preparation for light microscopy}

Inoculated stems were sampled for anatomical studies at 12,24 and $48 \mathrm{~h}$ after inoculation. Samples were first fixed in an acetic acid: ethanol: formaldehyde (Glacial Acetic Acid $5 \mathrm{ml}$ : Ethanol (70\%) 90ml: Formaldehyde $(38 \%) 5 \mathrm{ml}$ ) solution for $15 \mathrm{~h}$ and then were washed with distilled water for $8 \mathrm{~h}$. Cross sections were stained with $1 \%$ cotton blue in lactophenol ( $\mathrm{Li}$ et al., 2004) and rinsed in lactophenol for $10 \mathrm{~min}$. The sections were examined and photographed using a Zeiss Axioplan 2 microscope with a Nickon digital photograph system.

\section{Sample processing for Hemi-thin sections}

The infected segments of the sunflower stems were fixed in $2.5 \%$ glutaraldehyde in $0.05 \mathrm{M}$ phosphate buffer, $\mathrm{pH} 7.2$, for $48 \mathrm{~h}$ at room temperature. Material was post-fixed with $2 \%(\mathrm{w} / \mathrm{v})$ osmium tetroxide buffer for $2 \mathrm{~h}$ at $20^{\circ} \mathrm{C}$ before being dehydrated in a graded ethanol solutions ranging from 50\% to $100 \%$ (dry ethanol). Preparations were embedded in Spurr epoxy resin (Spurr, 1969). Hemi-thin sections (500nm thick) were cut on an Ultra Cut microtome and were mounted on glass slides and stained with Toluidine blue. Sections were examined with a Zeiss Light microscope.

\section{Results}

The light microscopic observations of the fungus in the sunflower basal stem are presented in Fig. 1, 2 and 3. There was a slight increase in the length of aerial mycelia on the basal stem and surface of the host tissue, $12 \mathrm{~h}$ after inoculation, which intensely stained by cotton blue (Fig. 1A). After contact with the host, appressorium was formed and the hyphal strands were branched. The hyphal apices on the surface of stem tissue showed dichotomous branching that gave rise to simple appresoria (Fig. 1B). Penetration proceeded directly through the cuticle (Fig. 1B).

After penetration of the host cuticle, hyphae were developed between the cuticle and the epidermal cell layer and in the cortex (Fig. 1C). The hyphae that moved into the cortex were developed inter- and intra-cellular levels (Fig. $1 \mathrm{D}, \mathrm{E}$ and F). After the initial infection period (12-24 h), the hyphae were branched and developed rapidly from the basal stem tissues. There was inter- and intra-cellular colonization of parenchyma (Fig. 2G), in which fungal hyphae was branched profusely. The hyphae continued growing in inter and intracellular spaces and extensively invaded the dead host tissues, 24-48 h after pathogen invasion. (Fig.
$2 \mathrm{H}, \mathrm{I}$ and $\mathrm{J})$. The ramifying hyphae also invaded the vascular tissues of sunflower stem and entered the vessels and interfascicular regions (Fig. 2J). As the infection progressed, the pathogen reached the pith of the stem (Fig. $2 \mathrm{H}$ and I). A $48 \mathrm{~h}$ after inoculation, host cells were disorganized and eventually collapsed (Fig. 2H, I and J). Hyphae were observed on the surfaces of stems after $48 \mathrm{~h}$.

The hemi-thin sectioning method was performed for better visualization of fungus penetration inside the plant tissues. The hemi-thin sections of inoculated stems were observed by light microscopy and the micrographs corresponded to the development of the fungus inside the host tissues. Toluidine blue stain and observations under bright light, was in agreement with our previous cotton blue staining results, indicating that hyphae of $S$. sclerotivorum is growing in inter and intra-cellular space of cortex tissue (Fig. 3A and B).

\section{Discussion}

Although the symptoms of Sclerotinia white rot disease have been described by various authors (Abawi et al., 1975; Garg et al., 2010; Rodriguez et al., 2004; Sedun and Brown, 1987), but the histological aspects of the infection of sunflower basal stem by $S$. sclerotiorum have not been documented. As first report, this study describes the infection process of $S$. sclerotiorum on the basal stem of a susceptible sunflower genotype.

The structural investigation of the artificial inoculation with S. sclerotiorum hyphae showed the occurrence of direct penetration through the cuticle in sunflower. The present study also reports the presence of subcuticular hyphae in basal stem of sunflower infected by $S$. sclerotiorum. Some other studies have shown that infection by $S$. sclerotiorum hyphae is usually penetrate directly through the cuticle (Abawi et al., 1975; Lumsden and Dow, 1973; Purdy, 1958), which is in agreement with the present results. Direct penetration has also been reported for other fungi such as Phoma macdonaldii in sunflower (Roustaee et al., 2000). Freeze and bruising injuries are important factors associated with infection of cabbage by $S$. sclerotiorum (Hudyncia et al., 2000). Tariq and Jeffries (1984) showed that infection of healthy tissue by myceliogenic infection depends on the formation of infection cushions on the host surface. The infection process is characterized by the formation of an appressorium, mechanical penetration of the cuticle and formation of inflated infection hyphae that develop inter and intracellular colonization of the host tissue (Lumsden and Wergin, 1980).

Infection cushions and/or appresoria were observed on the surface of stem base of studied genotype (Fig. 1B). It has been reported that appressoria were formed unless penetration occurs directly via stomata (Jones, 1976; Prior and Owen, 1964). Formation of these structures requires contact stimulus (Abawi et al., 1975; Garg et al., 2010; Purdy 1958). 
146

After contact with the host surface, the hyphal branch strands dichotomously formed dome-shaped infection cushions (Fig. 1B and C). Similarly, previous researches on $S$. sclerotiorum and other related pathogens such as $S$. trifoliorum and $S$. rolfsii also showed that the infection cushion assists with breaching the cuticle barrier of the host epidermis by applying mechanical pressure for fungal entry (Boyle, 1921; Garg et al., 2010; Lumsden and Dow, 1973; Lumsden and Wergin, 1980; Purdy, 1958) and/or by enzymatic disintegration of the host surface (Prior and Owen, 1964; Tariq and Jeffries, 1986). However, dissolvement of the cuticle and epidermal cells, which results from enzyme function, is occurred when the infection cushions appear.

Microscopic observation of tissues $24 \mathrm{~h}$ post inoculation revealed that fungal hyphae have extensively devel-
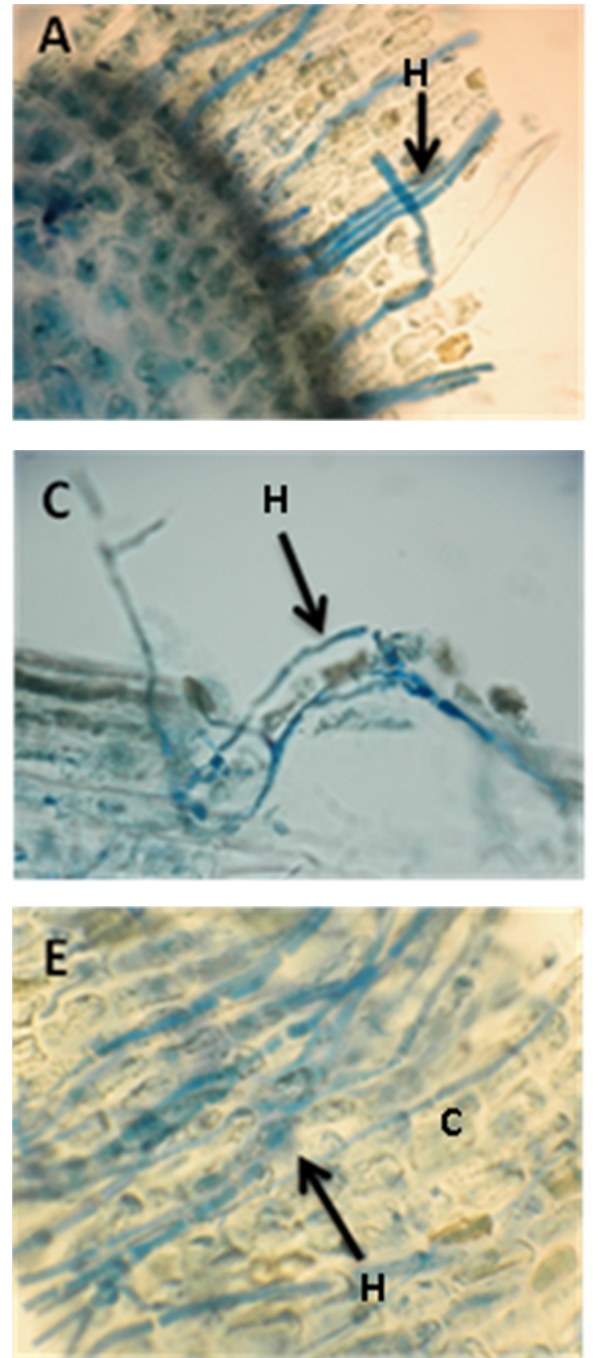

oped at both inter and intracellular levels and growing between and through cells (Fig. 1D, E, F and 3A, B). These observations clearly resembled the previous reports, in which penetration of host tissue by hyphae have been described at inter and intracellular levels (Abawi et al., 1975; Purdy, 1958).

Undoubtedly, the infection hyphae are responsible for breaching the host's defenses and initiate colonization of host tissue. The infection hyphae are associated with the advancing margins of visible lesions on hosts (Boyle, 1921; Lumsden and Dow, 1973). These hyphae probably are responsible for changes in infected host tissue which include histological alterations in pectic materials in cell walls (Lumsden and Dow, 1973), death of cells (Boyle, 1921; Hancock, 1972), copious accumulation of fluids
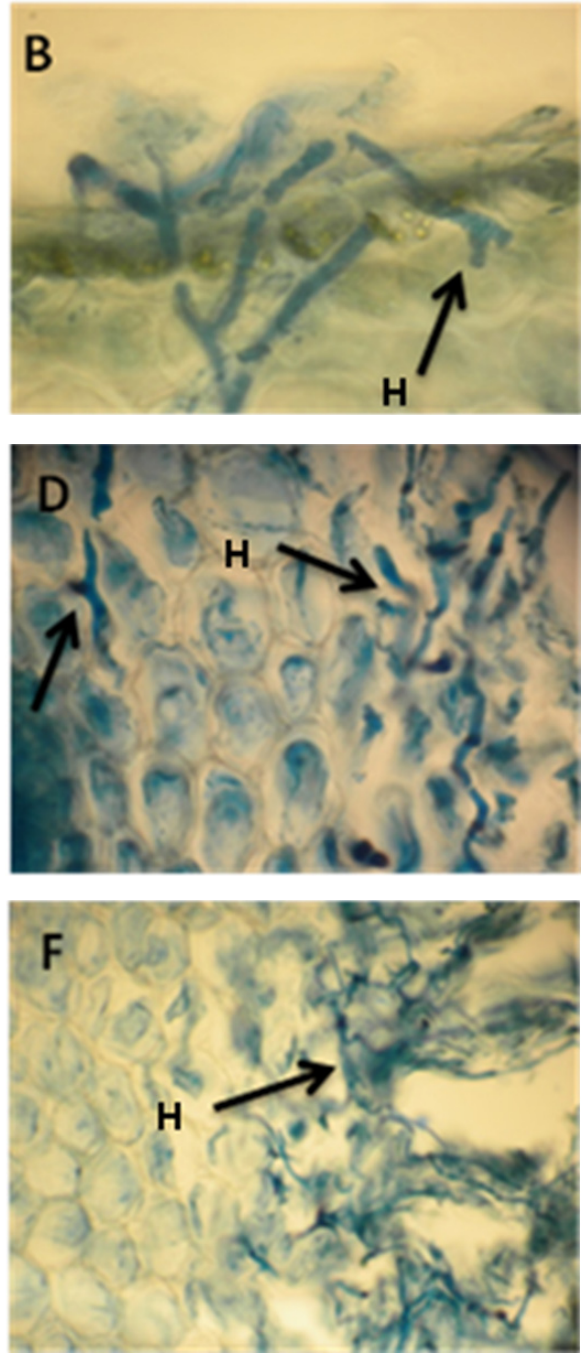

Fig. 1. Light micrographs following inoculation of S. sclerotiorum isolate SSU107 onto basal stem of susceptible 'C146' sunflower (A-F). The samples were fixed in an acetic acid: ethanol: formaldehyde solution, stained with $1 \%$ Cotton Blue in lactophenol, and photographed using a Zeiss Axioplan 2 microscope photograph system. Arrows indicate fungal hyphae. Micrographs showing increase in the aerial hyphae on basal stem (A), appressorium formation, hyphal branching (B), development of hyphae and colonization of the fungus $12(\mathrm{C}, \mathrm{D})$ and $24 \mathrm{~h}(\mathrm{E}, \mathrm{F})$ after inoculation. In inoculated tissues after 24 hours (E and F) revealed that fungal hyphae growth was incremental among and inside the host cells. $\mathrm{H}=$ hyphae, $\mathrm{C}=$ Cortex 

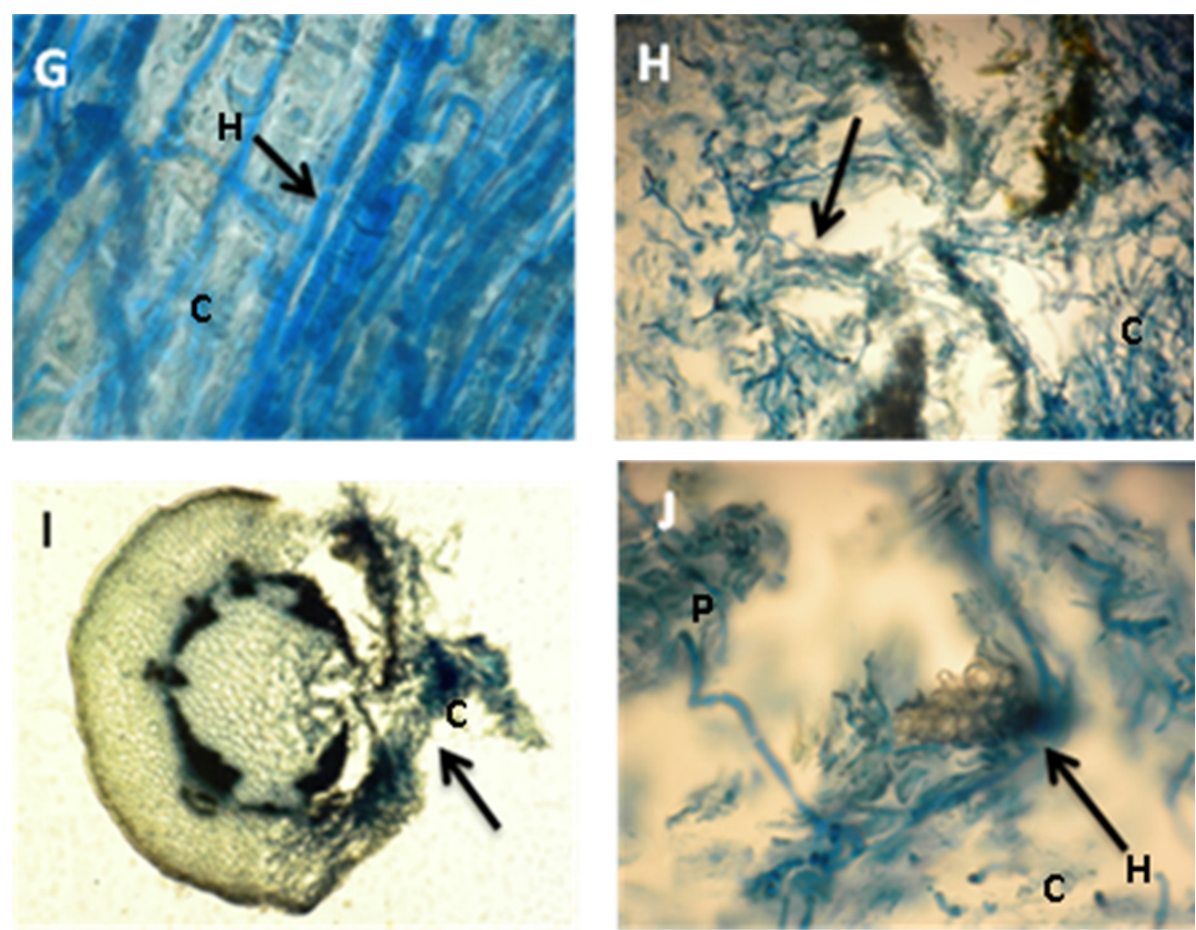

Fig. 2. Light micrographs on infection and extension of $S$. sclerotiorum in host tissues. Cross sections showing the penetration of $S$. sclerotiorum isolate SSU107 into basal stem of sunflower $48 \mathrm{~h}$ after inoculation. Samples were fixed in an acetic acid: ethanol: formaldehyde solution, stained with 1\% Cotton Blue in lactophenol. G-J Micrographs showing development of the hyphae and colonization of the fungus $48 \mathrm{~h}$ after inoculation. Micrographs showing dense colonization of stem tissue by hyphae of $S$. sclerotiorum $(\mathrm{G})$. The hyphae had entered into the host tissues $(\mathrm{H})$. Host cortical cell disintegrate after sclerotinia invasion (H, I and J). Arrows indicate fungal hyphae. $\mathrm{C}=$ Cortex, $\mathrm{H}=$ Hyphae, $\mathrm{P}=$ Pith

and water-soaking in advancing margins (Hancock, 1972; Lumsden and Dow, 1973).

Lumsden and Dow (1973) demonstrated that after colonization of host tissue by Sclerotinia infection hyphaehyphal (12-24 h after penetration), branches are developed and extensively ready to invade the dead host tissue by penetrating cell walls at both inter and intracellular levels. This was evidently observed in the histological examination of the study that extensive colonization of cells caused the death of stem tissues cells (Fig. 1F, 2H, I and J). Rodriguez et al. (2004) reported inter and intracellular colonization and cell collapse in flower tissues of sunflower. This might be related to changes occurring in tissues in response to the pathogen, such as cell collapse and changes in cell wall composition. Cosson et al. (1993) and PrattsPérez et al. (2000) studied wild and cultivated genotypes of sunflower and identified that necrotized tissues synthesize compounds which appear to be phytoalexins.

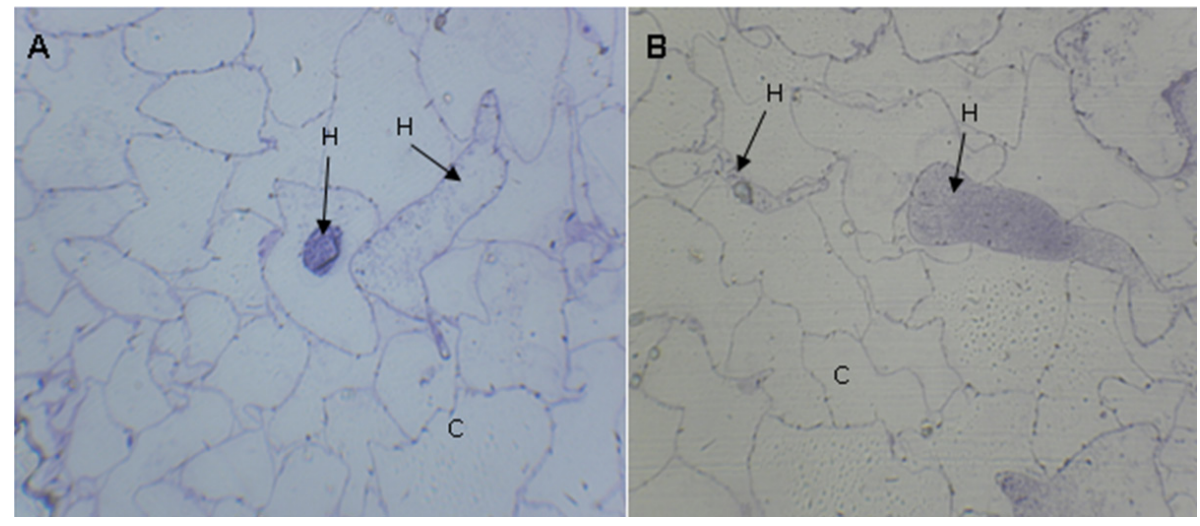

Fig. 3. Hemi-thin cross section showing colonized hyphae which spread inter and intracellularly in the infected stem tissue. (A and B) Observations made using light microscopy. Sections showing that fungal hyphae appear stained with toluidine blue within the stem tissues. The hyphae were developed among and inside of cortex cells. Arrows indicate fungal hyphae. $\mathrm{H}=$ hyphae, $\mathrm{C}=\mathrm{Cor}-$ tex 
148

Pathogenesis is a complex progress involving the pathogen's inherent capabilities and multiple factors that govern penetration and infection of a host plant. The host plant has various defense mechanisms that must be inactivated or nullified before a disease can be developed. This interaction between host and pathogen also depends on the environmental factors. The pathogen's invasion mechanisms include producing the cell wall and middle lamella dissolving enzymes, toxins, enzymes to degrade host tissue and defense substances, and rapidity in host plant infection. S. sclerotiorum facilitates penetration and colonization of host plant tissues by secreting multiple pectinolytic enzymes.

The present study has detailed the infection processes and pathogen development both on the plant surface and inside the host tissues. These results can be used for strategic engineering of disease-resistant genotypes and developing markers for screening of resistance individuals.

\section{Acknowledgements}

The authors gratefully thank Institute of Biotechnology, Urmia University, Iran, for their valuable supports on this work.

\section{References}

Abawi GS, Grogan RG (1975). Source of primary inoculum and effects of temperature and moisture on infection of beans by Whetzelinia sclerotiorum. Phytopathol 65:300-309.

Annis SL, Goodwin PH (1997). Recent advances in molecular genetics of plant cell wall degrading enzymes in plant pathogenic fungi. Europ J Plant Pathol 103:1-14.

Boland GJ, Hall R (1994). Index of plant hosts of Sclerotinia sclerotiorum. Canad J Plant Pathol 16:93-108.

Bolton MD, Thomma BPHJ, Nelson BD (2006). Sclerotinia sclerotiorum (Lib.) de Bary: biology and molecular traits of a cosmopolitan pathogen. Molecular Plant Pathology 7:1-16.

Boyle C (1921). Studies in the physiology of parasitism. VI. Infection by Sclerotinia libertiana. Ann Rev Bot 35:337347.

Cosson L, Serieys H, Tourvieille D, Andary C (1993). Resistance factors of cultivated and wild sunflowers to Sclerotinia sclerotiorum, 385-400 p. In: Friting B, Legrand M (Eds). Mechanisms of Plant Defense Responses. Netherlands: Kluwer Academic Publishers.

Davar R, Darvishzadeh R, Majd A, Gousta Y, Sarrafi A (2010). QTL mapping of partial resistance to basal stem rot in sunflower using recombinant inbred lines. Phytopathol Med 49:330-341.

de Bary A (1886). Ueber einige Sclerotinien und Sclerotienkrankheiten. Botanische Zeitimg 44:374-474.

de Bary A (1887). Comparative morphology and biology of the fungi, mycetozoa and bacteria. Oxford: Clarendon Press.

Donaldson PA, Anderson T, Lane BG, Davidson AL, Simmonds
DH (2001). Soybean plants expressing an active oligomeric oxalate oxidase from the wheat gf- 2.8 (germin) gene are resistant to the oxalate-secreting pathogen Sclerotinia sclerotiorum. Physiol Molec Plant Pathol 59:297-307.

Dorrell DG, Huang HC (1978). Influence of Sclerotinia Wilt on seed yield and quality of sunflower wilted at different stages of development. Crop Sci 18:974-978.

Godoy G, Steadman JR, Dickman MB, Dam R (1990). Use of mutants to demonstrate the role of oxalic acid in pathogenicity of Sclerotinia sclerotiorum on Phaseolus vulgaris. Physiol Molec Plant Pathol 37:179-191.

Gulya T, Rashid KY, Masireviæ SM (1997). Sunflower diseases, 263-379 p. In: Sunflower Technology and Production Schneiter AA (Ed.). ASA, CSSA, SSSA, Madison, WI, USA.

Garg H, Li H, Sivasithamparam K, Kuo J, Barbetti MJ (2010). The infection processes of Sclerotinia sclerotiorum in cotyledon tissue of a resistant and a susceptible genotype of Brassica napus. Ann Bot 106:897-908.

Hancock JG (1972). Changes in cell membrane permeability in sunflower hypocotyls infected with Sclerotinia sclerotiorum. Plant Physiol 49:358-364.

Hahn V (2002). Genetic variation for resistance to sclerotinia head rot in sunflower inbred lines. Field Crops Res 77:153159.

Holley RC, Nelson B (1986). Effect of plant population and inoculums density on incidence of sclerotinia wilt of sunflower. Phytopathol 76:71-74.

Huang HC, Kokko EG (1992). Pod rot of dry peas due to infection by ascospores of Sclerotinia sclerotiorum. Plant Disease 76:597-600.

Huang L, Buchenauer H, Han Q, Zhang X, Kang Z (2008). Ultrastructural and cytochemical studies on the infection process of Sclerotinia sclerotiorum in oilseed rape. J Plant Dis Protect 115:9-16.

HudynciaJ, Shew HD, Cody BR, Cubeta MA (2000). Evaluation of wounds as a factor to infection of cabbage by ascospores of Sclerotinia sclerotiorum. Plant Disease 84:316-320.

Isacc S (1992). Fungal-Plant Interactions. Chapman and Hall, London.

Jones D (1976). Infection of plant tissue by Sclerotinia sclerotiorum: a scanning electron microscope study. Micron 7:275-279.

Li H, Sivasithamparam K, Barbetti MJ, Kuo J (2004). Germination and invasion by ascospores and pycnidiospores of Leptosphaeria maculans on spring-type Brassica napus canola varieties with varying susceptibility to blackleg. J General Plant Pathol 70:261-269.

Li CX, Liu SY, Sivasithamparam K, Barbetti MJ (2008). New sources of resistance to sclerotinia stem rot caused by Sclerotinia sclerotiorum in Chinese and Australian Brassica napus and Brassicajuncea germplasm screened under Western Australian conditions. Austr Plant Pathol 38:149-152. 
Lumsden RD (1976). Pectolytic enzymes of Sclerotinia sclerotiorum and their localization in infected bean. Canad J Bot 54:2630-2641.

Lumsden RD, Dow RL (1973). Histopathology of Sclerotinia sclerotiorum infection of bean. Phytopathol 63:708-715.

Lumsden RD, Wergin WP (1980). Scanning electron microscopy of infection of bean by species of Sclerotinia. Mycologia 72:1200-1209.

Marciano P, Lenna PDI, Magro P (1982). Polygalacturonase isoenzymes produced by Sclerotinia sclerotiorum in vivo and in vitro. Physiol Plant Pathol 20:201-212.

Marciano P, Lenna PDI, Magro P. (1983). Oxalic acid, cell wall-degrading enzymes and $\mathrm{pH}$ in pathogenesis and their significance in the virulence of two Sclerotinia sclerotiorum isolates on sunflower. Physiol Plant Pathol 22:339-345.

Maxwell DP, Lumdsen RD (1970). Oxalic acid production by Sclerotinia sclerotiorum in infected bean and in culture. Phytopathol 60:1395-1398.

Poormohammad Kiani S, Talia P, Maury P, Grieu P, Heinz R, Perrault A, Nishinakamasu V, Hopp E, Gentzbittel L, Paniego N, Sarrafi A (2007). Genetic analysis of plant water status and osmotic adjustment in recombinant inbred lines of sunflower under two water treatments. Plant Sci 172:773787.

Pratts-Pérez E, Bazzalo ME, León A, Jorrin-Novo JV (2000). Accumulation of soluble phenolic compounds in sunflower capitula correlates with tolerance to Sclerotinia sclerotiorum. $15^{\text {th }}$ International Sunflower Conference Vol. II K-35-K41. June 12-15, Touluse France.

Price K, Colhoun J (1975). A study of variability of isolates of Sclerotinia sclerotiorum (Lib.) de Bary from different hosts. J Phytopathol 83:159-166.

Prior GD, Owen JH (1964). Pathological anatomy of Sclerotinia trifoliorum on clover and alfalfa. Phytopathol 54:784-787.

Purdy LH (1958). Some factors affecting penetration and infection by Sclerotinia sclerotiorum. Phytopathol 48:605609.
149

Purdy LH, Bardin R (1953). Mode of infection of tomato plants by the ascospores of Sclerotinia sclerotiorum. Plant Disease Rep 37:361-362.

Riou C, Freyssinet G, Fevre M (1991). Production of cell wall-degrading enzymes by the phytopathogenic fungus Sclerotinia sclerotiorum. Appl Environ Microbiol 57:14781484.

Rodriguez MA, Venedikian N, Bazzalo ME, Godeas A (2004). Histopathology of Sclerotinia sclerotiorum attack on flower parts of Helianthus annuus heads in tolerant and susceptible varieties. Mycopathol 157:291-302.

Roustaee A, Dechamp-Guillaume G, Geile B, Savy C, Dargent $R$, Barrault $G$ (2000). Ultrastructural studies of the mode of penetration by Phoma macdonaldii in sunflower seedlings. Phytopathol 8:915-920.

Sackston WE (1992). On a treadmill: Breeding sunflowers for resistance to disease. Ann Rev Phytopathol 30:529-551.

Saharan GS, Mehta N (2008). Sclerotinia Diseases of Crop Plants: Biology, Eology and Disease Management. LXII. Springer-Verlag GmbH, Heidelberg.

Schneiter AA, Miller JF (1981). Description of sunflower growth stages. Crop Sci 21:901-903.

Sedun FS, Brown JF (1987). Infection of sunflower leaves by ascospores of Sclerotinia sclerotiorum. Ann Appl Biol 110:275-284.

Spurr AR (1969). A low-viscosity epoxy resin embedding medium for electron microscopy. J Ultrastruct Res 26:3143.

Sutton DC, Deverall BJ (1983). Studies on infection of bean (Phaseolus vulgaris) and soybean (Glycine max) by ascospores of Sclerotinia sclerotiorum. Plant Pathol 32:251-261.

Tariq VN, Jeffries P (1984). Appressorium formation by Sclerotinia sclerotiorum: scanning electron microscopy. Transact British Mycol Soc 82:645-651.

Tariq VN, Jeffries P (1986). Ultrastructure of penetration of Phaseolus spp. by Sclerotinia sclerotiorum. Canad J Bot 64:2909-2915. 